\title{
HUBUNGAN ANTARA PENGGUNAAN TELEPON PINTAR DENGAN KEJADIAN NYERI LEHER PADA INDIVIDU DEWASA MUDA
}

\author{
Komang Wisma Mitra Kenwa ${ }^{1}$, I Gusti Ngurah Purna Putra² ${ }^{2}$ Thomas Eko Purwata ${ }^{2}$
}

${ }^{1}$ Program Studi Pendidikan Dokter, FK Universitas Udayana, Denpasar, Bali, Indonesia

${ }^{2}$ Departemen Neurologi, FK Universitas Udayana/RSUP Sanglah, Denpasar, Bali, Indonesia

Diterima 26 Juni 2018

Disetujui 02 September 2018

Publikasi 21 September 2018

Korespondensi: kenwakomang@gmail.com
Cara merujuk artikel ini: Kenwa (et al). 2018. Hubungan Antara Penggunaan Telepon Pintar Dengan Kejadian Nyeri Leher Pada Individu Dewasa Muda. Callosum Neurology Journal 1(3): 78-72. DOI: https://doi.org/10.29342/cnj.v1i3.16

\section{ABSTRAK}

Latar Belakang: Beberapa masalah yang muncul dalam penggunaan telepon genggam antara lain efek kecanduan, antisosial, dan permasalahan kesehatan seperti nyeri pada leher, lelah otot, dan kaku otot.

Tujuan: Untuk mengetahui adanya hubungan antara penggunaan telepon pintar dengan kejadian nyeri leher pada dewasa muda berusia 18-24 tahun.

Metode Penelitian: Penelitian ini menggunakan desain penelitian potong lintang yang dilakukan di Fakultas Kedokteran Universitas Udayana dengan menggunakan kuesioner mengenai kebiasaan penggunaan telepon pintar dan mengenai riwayat nyeri leher.
Hasil: Terdapat 118 responden dengan proporsi perempuan 89 orang $(75,4 \%)$ dan laki-laki yaitu 20 orang $(24,6 \%)$. Usia rata-rata responden adalah 19,4 tahun. Akumulasi durasi penggunaan telepon pintar rata-rata 7,54 jam. Prevalensi nyeri leher adalah 83,1\% dengan rata-rata skala nyeri leher adalah 2,79. Simpulan: Terdapat hubungan lemah namun bermakna antara durasi penggunaan telepon pintar dengan kejadian nyeri leher pada individu dewasa muda.

Kata Kunci: Durasi Pemakaian, Telepon Pintar, Nyeri Leher, Dewasa Muda

\section{ABSTRACT}

Background: Some problems that arise in the use of mobile phones include addictive effects, antisocial, and emerging health problems such as neck pain, muscle fatigue, and muscle stiffness.

Purpose: To determine the relationship between the use of smart phones with the occurrence of neck pain in young adults aged 18-24 years.

Methods: This study used cross-sectional design conducted at the Faculty of Medicine Udayana University using a questionnaire.
Result: There were 118 respondents with women 89 (75.4\%) and men 20 (24.6\%). The average age was 19.4 years. Average of phone usage duration was 7.54 hours. The prevalence of neck pain was found $83.1 \%$ with mean of neck pain scale is 2.79 . Conclusion: There is a significant weak relationship between duration smart phones usage and incidence of neck pain in young adults. Keywords: Duration of usage, Smartphone, Neck Pain, Young Adults. 


\section{Latar Belakang}

Telepon genggam sudah menjadi hal yang umum dimiliki di era digital. Lapisan masyarakat dari kalangan berbagai usia setidaknya telah menggunakan telepon genggam. Bahkan beberapa orang memiliki lebih dari satu telepon genggam untuk berbagai keperluan seperti keperluan bisnis dan keluarga. ${ }^{1}$ Penggunaan telepon genggam yang tidak dibatasi seperti ini dapat menimbulkan efek negatif dari telepon genggam itu sendiri. ${ }^{2}$ Beberapa masalah yang muncul dalam penggunaan telepon genggam antara lain efek kecanduan, anti sosial, dan muncul permasalahan kesehatan seperti nyeri pada leher, lelah otot, dan kaku otot. ${ }^{3,4}$

Leher menyokong berat dari kepala dan bersifat sangat fleksibel, menyebabkan kepala dapat berputar dan menekuk. Leher adalah bagian yang sangat penting bagi manusia. ${ }^{5}$ Secara anatomi, pada leher terdapat tujuh ruas tulang belakang dengan kode $\mathrm{C} 1-\mathrm{C} 7$ dengan $\mathrm{C} 1$ adalah tulang atlas dan C2 adalah tulang aksis. Sisa tulang C3 sampai C7 tergabung secara superior dan inferior pada diskus intervertebralis. Nyeri leher adalah nyeri yang terdapat pada area leher. Nyeri leher ini terjadi akibat posisi leher yang tidak benar dalam waktu yang cukup lama dan terpusat pada bagian belakang leher hingga ke tengkuk. ${ }^{6}$

Nyeri pada leher memiliki banyak penyebab dimana faktor utama adalah posisi tubuh yang salah sehingga membuat leher berada dalam posisi tertentudalam jangka waktu lama misalnya pada pengguna komputer atau tukang angkut. ${ }^{7}$ Selain itu perubahan posisi leher juga terjadi pada pengguna telepon genggam. Terdapat keterkaitan antara kelelahan otot dengan nyeri leher. Ketika seseorang menggunakan telepon genggam, leher akan fleksi ke bawah untuk melihat telepon genggam dan dipertahankan dalam waktu yang relatif lama sehingga menimbulkan masalah otot dan apabila dibiarkan dapat menjadi nyeri otot kronis. ${ }^{4}$

Pada kejadian nyeri leher, otot mengalami kontraksi yang berlebihan menyebabkan kondisi yang lelah dari leher khususnya pada otot-otot di sekitar leher dan punggung seperti otot sternokleidomastoideus yang diperlukan untuk menoleh kiri dan kanan, serta otot trapezius pada leher dan punggung yang mengakibatkan penjalaran nyeri pada leher ke arah punggung. ${ }^{8}$

Penelitian yang membahas mengenai perubahan posisi leher pada pengguna telepon genggam telah banyak dilakukan tetapi masih belum terdapat penelitian yang membahas mengenai dampak dari perubahan posisi leher tersebut pada pengguna telepon genggam yaitu kejadian nyeri leher. Maka dari itu perlu diadakan penelitian yang khusus membahas mengenai apakah penggunaan telepon genggam dapat mempengaruhi terjadinya kejadian nyeri leher berkaitan dengan perubahan posisi leher pada pengguna telepon genggam.

Peneliti menyadari masih diperlukan penelitian lainnya yang serupa untuk dapat mendukung penelitian ini sehingga dapat menjadi bahan pertimbangan salah satu penyebab dari nyeri leher adalah dengan penggunaan telepon genggam.

\section{Metode Penelitian}

Penelitian ini menggunakan desain studi potong lintang. Penelitian ini telah dinyatakan laik etik oleh Komisi Etika Penelitian Fakultas Kedokteran Universitas Udayana/ Rumah Sakit Umum Pusat Sanglah Denpasar berdasarkan surat No:2163/ UN.14.2/ KEP/ 2017 pada tanggal 29 September 2017.

Penelitian dilakukan di Fakultas Kedokteran Universitas Udayana. Penelitian dilakukan pada bulan Februari hingga Juni 2017.

Adapun populasi terjangkau adalah mahasiswa Fakultas Kedokteran Universitas Udayana yang terdiri atas enam program studi dengan kriteria inklusi berupa umur 18-24 tahun dan memiliki jenis telepon pintar layar sentuh dengan sistem operasi apapun dan ukuran antara 4-6,5 inci. Sedangkan kriteria eksklusi dari penelitian ini adalah dewasa muda dengan kelainan otot pada leher, penyakit kronis lainnya, serta tidak bersedia mengikuti dan mengisi kuesioner.

Sampel diambil dengan menggunakan teknik simple random sampling. Sampel diambil secara merata pada enam program studi di Fakultas Kedokteran yaitu Pendidikan Dokter, IImu Keperawatan, Kesehatan Masyarakat, Psikologi, Fisioterapi, dan Pendidikan Dokter Gigi.

Variabel bebas dari penelitian ini adalah akumulasi durasi penggunaan telepon pintar dalam sehari. Variabel terikat adalah kejadian nyeri leher dan tingkat nyeri leher menggunakan skala nyeri dalam angka dari 0 menandakan tidak nyeri hingga 10 menandakan nyeri yang sangat luar biasa.

Tabel 1. Uji Normalitas Sampel

\begin{tabular}{lcc}
\hline Uji Kormogorov-Smirnov & $p$ & Keterangan \\
\hline Durasi penggunaan & $<0,001$ & Tidak \\
Normal \\
Skala Nyeri & $<0,001$ & Tidak \\
& Normal \\
\hline
\end{tabular}


Data dianalisis secara bivariat menggunakan uji korelasi antara variabel bebas dan variabel terikat. Uji normalitas data menggunakan uji KolmogorovSmirnov dengan nilai p sebesar $<0,001$ pada durasi penggunaan telepon pintar dan skala nyeri. Hal ini menandakan sebaran data tidak normal.

Berdasarkan uji normalitas tersebut maka uji korelasi untuk persebaran data yang tidak normal adalah uji non parametrik yaitu uji Spearman.

\section{Hasil Penelitian}

Data sampel yang didapat berjumlah 118 responden dari enam program studi dan empat angkatan (2014-2017) dengan karakteristik sampel seperti pada Tabel 2. Berdasarkan Tabel 2, sebaran jenis kelamin laki laki sebanyak 29 orang (24,6\%) dan perempuan sebanyak 89 orang $(75,4 \%)$. Jumlah respoden tiap program studi sebanyak 20 orang dari Pendidikan Dokter, Kesehatan Masyarakat, Psikologi, Fisioterapi, dan Kedokteran Gigi serta 18 responden dari Ilmu Keperawatan. Pada penelitian ini responden dipilih secara acak dengan memperhatikan kriteria inklusi dan eksklusi. Terdapat data yang hilang pada program studi Ilmu Keperawatan sebanyak dua data dan tidak diikutsertakan dalam analisis dan penarikan kesimpulan.

\section{Tabel 2. Distribusi Karakteristik Sampel}

\begin{tabular}{|c|c|c|}
\hline Karakteristik & $\begin{array}{c}\text { Jumlah } \\
(n=129)\end{array}$ & $\begin{array}{c}\text { Persen } \\
(\%)\end{array}$ \\
\hline \multicolumn{3}{|l|}{ Jenis kelamin } \\
\hline Laki-laki & 29 & 24,6 \\
\hline Perempuan & 89 & 75,4 \\
\hline \multicolumn{3}{|l|}{ Program studi } \\
\hline Pendidikan Dokter & 20 & 16,9 \\
\hline Ilmu Keperawatan & 18 & 15,3 \\
\hline Kesehatan & 20 & 16,9 \\
\hline Masyarakat Psikologi & 20 & 16,9 \\
\hline Fisioterapi & 20 & 16,9 \\
\hline Kedokteran Gigi & 20 & 16,9 \\
\hline \multicolumn{3}{|l|}{ Angkatan } \\
\hline 2014 & 22 & 18,6 \\
\hline 2015 & 38 & 32,2 \\
\hline 2016 & 30 & 25,4 \\
\hline 2017 & 28 & 23,7 \\
\hline Usia (rata-rata) & \multicolumn{2}{|c|}{19,4 tahun } \\
\hline \multicolumn{3}{|l|}{ Durasi } \\
\hline penggunan & \multirow{2}{*}{\multicolumn{2}{|c|}{$\begin{array}{c}7,54 \text { jam } \\
20 \text { jam }\end{array}$}} \\
\hline $\begin{array}{l}\text { Rata-rata } \\
\text { maksimal }\end{array}$ & & \\
\hline \multicolumn{3}{|l|}{ Nyeri } \\
\hline leher Ya & 98 & 83,1 \\
\hline Tidak & 20 & 16,9 \\
\hline
\end{tabular}

Skala nyeri leher

Rata-rata

$2,79(0-8)$

Rerata usia sampel adalah 19,40 dengan jumlah usia terbanyak adalah 19 tahun dan rentangan antara 18-23 tahun. Gambaran sebaran angkatan dari sampel yaitu angkatan 2014 sebanyak 22 orang (18,6\%), angkatan 2015 sebanyak 38 orang (32,2\%), angkatan 2016 sebanyak 30 orang $(23,7 \%)$, dan angkatan 2017 sebanyak 28 orang $(23,7 \%)$.

Tabel 3. Hubungan durasi penggunaan ponsel dan nyeri leher

\begin{tabular}{llrr}
\hline \multicolumn{1}{c}{ Uji Spearman } & $\begin{array}{c}\text { Durasi } \\
\text { Penggunaan } \\
\text { Telepon } \\
\text { Pintar }\end{array}$ & $\begin{array}{c}\text { Skala } \\
\text { Nyeri }\end{array}$ \\
\hline $\begin{array}{l}\text { Durasi } \\
\text { Penggunaan }\end{array}$ & Koefisien & 1,000 & 0,209 \\
Telepon & korelasi & 0,023 & 118 \\
Pintar & N & 118 & 1,000 \\
Skala Nyeri & Koefisien & 0,209 & \\
& korelasi & & 118 \\
\hline & Sig & 0,023 & \\
& $\mathrm{~N}$ & 118 & \\
\hline
\end{tabular}

Durasi penggunaan telepon pintar rata-rata 7,54 jam. Pada durasi penggunaan telepon pintar juga ditemukan rentangan antara 1-20 jam. Pada bagian nyeri leher didapatkan sebanyak 98 responden mengaku pernah mengalami nyeri leher dalam sebulan terakhir (83,1\%) dan sebanyak 20 responden mengaku tidak pernah mengalami nyeri leher sebelumnya dengan rerata skala nyeri menurut angka 2,79 dan skala maksimal adalah 8. Berdasarkan uji korelasi pada tabel 3 menunjukan bahwa terdapat hubungan yang lemah $(0,209)$ yang bermakna antara durasi penggunaan telepon pintar dengan skala nyeri menurut NRS $(p=0,023)$. Hal tersebut menunjukkan bahwa semakin meningkatnya durasi penggunaan telepon pintar maka skala nyeri leher juga akan mengalami peningkatan.

Hasil perhitungan estimasi risiko menggunakan uji Chi-Square pada tabel 4 menunjukkan terdapat hubungan yang signifikan antara durasi 7 jam ke atas dan nyeri leher sedang dan berat $(p=0,022)$ dengan estimasi risiko 2,803 (IK $95 \%=1,089$ $7,216)$ menunjukkan penggunaan telepon pintar selama 7 jam ke atas meningkatkan risiko sebesar 2,8 kali mengalami nyeri leher sedang dan berat. 
Tabel 4. Hasil Analisis Chi-square pada Variabel yang Telah Dikelompokkan

\begin{tabular}{cc} 
Data & Nilai \\
\hline
\end{tabular}

Pembahasan

Pada penelitian ini responden dipilih secara acak dengan memperhatikan kriteria inklusi dan eksklusi. Terdapat data yang hilang pada program studi ilmu keperawatan sebanyak 2 data dan tidak diikutsertakan dalam analisis dan penarikan kesimpulan. Berdasarkan analisis data didapatkan kejadian nyeri leher sebanyak $83,1 \%$ dengan terdapat hubungan lemah yang bermakna antara durasi penggunaan telepon pintar dan peningkatan skala nyeri leher.

Sebuah penelitian yang dilakukan di Jordan University of Science and Technology, Amerika Serikat tahun 2017 pada gabungan tenaga kesehatan dengan rata-rata usia 21,3 tahun menemukan bahwa prevalensi nyeri leher pada mahasiswa tenaga kesehatan adalah 67,1\%. ${ }^{9}$ Penelitian lainnya di Korea Selatan pada mahasiswa ditemukan bahwa nyeri pada leher dan punggung adalah nyeri yang paling sering dialami saat menggunakan telepon pintar yaitu berturut-turut $55,8 \%$ dan $54,8 \%{ }^{8} \quad$ Angka tersebut menunjukan pada penelitian ini prevalensi nyeri pada leher masih lebih tinggi dibandingkan penelitian sebelumnya.

Penelitian mengenai pengaruh penggunaan telepon pintar dengan kejadian nyeri leher telah banyak diteliti. Penelitian telah dilakukan di Chungbuk U1 University pada tahun 2017 yang meneliti kaitan antara sudut leher (CROM/Cervical Range of Motion) pada penggunaan telepon pintar dengan kejadian kelelahan pada leher dan daerah punggung atas (otot trapezius) menggunakan elektroda elektromiografi. Penelitian yang dilakukan terhadap 14 orang dewasa muda dengan rata-rata usia 22,1 \pm 1,6 tahun menunjukan bahwa terdapat hasil signifikan pada kelelahan dan nyeri pada otot punggung dan hasil yang tidak signifikan pada nyeri leher. ${ }^{10} \quad$ Penelitian lainnya pada tahun 2015 menemukan bahwa semakin lama dalam penggunaan telepon genggam menyebabkan semakin berubahnya posisi leher yang menyebabkan signifikan $(p<0,05)$ terhadap kejadian nyeri leher ringan. ${ }^{8}$ Pada penelitian ini penelitian melakukan perbandingan korelasi antara durasi dalam penggunaan telepon pintar dan skala nyeri leher yang belum pernah dilakukan pada penelitian sebelumnya. Sebuah ulasan sistematis menyebutkan bahwa nyeri pada leber berkaitan dengan waktu penggunaan telepon pintar di meja

\begin{tabular}{cc}
\hline$p$ & 0,022 \\
Rasio Prevalensi & 2,803 \\
IK 95\% & $1,089-7,216$ \\
\hline
\end{tabular}

atau di pangkuan dengan posisi leher yang sedikit miring ke depan. ${ }^{11}$ Penelitian sebelumnya oleh Almhdawi di Amerika Serikat pada tahun 2017 menunjukan terdapat hubungan yang signifikan antara kejadian nyeri leher, punggung, dan pinggang dengan durasi penggunaan telepon pintar tetapi penelitian ini tidak meneliti seberapa kuat hubungan diantaranya. ${ }^{9}$ Penelitian lainnya di Seoul, Korea Selatan menemukan bahwa penggunaan telepon pintar untuk internet dan sosial media memiliki keluhan nyeri yang lebih tinggi dan penggunaan telepon genggam kurang dari 2 jam memiliki keluhan yang lebih sedikit dibandingkan penggunaan lebih dari 2 jam. Tetapi pada penelitian tersebut menemukan bahwa tidak terdapat hubungan yang signifikan antara lama penggunaan telepon pintar dengan nyeri pada mata, leher dan pada lengan sedangkan terdapat hubungan signifikan dengan nyeri pada tangan, pergelangan tangan, dan jari. ${ }^{8}$ Hasil dari penelitian ini dapat berguna dalam memahami berbagai hal. Pertama, pada mahasiswa Fakultas Kedokteran Universitas Udayana memiliki angka prevalensi nyeri leher yang cukup tinggi dibandingkan penelitian serupa di berbagai wilayah. Kedua, dapat menyediakan informasi mengenai nyeri leher yang dirasakan berkaitan dengan lama waktu penggunaan telepon pintar sehingga dapat menjadi lebih bijak dalam menggunakan telepon pintar.

Ketiga, data hubungan korelasi yang kecil antara durasi penggunaan telepon pintar dengan skala nyeri leher menunjukkan terdapat faktor lainnya yang dapat memperberat skala nyeri leher sehingga perlu dilakukan penelitian lebih mendalam terkait tema tersebut mengingat prevalensi nyeri leher yang cukup tinggi. Penelitian ini memiliki keterbatasan yaitu menggunakan metode sekali pengukuran dan meihat faktor risiko nyeri leher lainnya karena fokus terkait dengan durasi penggunaan telepon pintar.

\section{Simpulan}

Berdasarkan hasil penelitian yang didapat, dapat disimpulkan bahwa terdapat hubungan lemah yang bermakna antara durasi lama penggunaan telepon pintar dengan meningkatnya skala nyeri leher dan menggunakan telepon pintar selama 7 jam atau lebih meningkatkan risiko sebesar 2,8 kali untuk terkena nyeri leher sedang dan berat.

Saran yang dapat diambil dari penelitian tersebut 
diantaranya perlu dilakukannya penelitian lanjutan mengenai faktor risiko nyeri leher mengingat angka kejadian nyeri leher yang cukup tinggi, mengenai bagaimana penggunaan telepon pintar dapat mengakibatkan kejadian nyeri leher, serta perlu

\section{Daftar Rujukan}

1. Rosley NM, Ismail I, Visvernardan HL. Students' Acceptance on Mobile Phone Usage and SMS Learning. Malaysian J Distance Educ. 2011;13(2):49-59.

2. Lee WJ, Shin S. A Comparative Study of Smartphone Addiction Drivers' Effect on Work Performance in the U.S. and Korea. J Appl Bus Res. 2016;32(2):507-16.

3. Mutchler LA, Shim JP, Ormond D. Exploratory study on users' behavior: Smartphone usage. 17th Am Conf Inf Syst 2011, AMCIS 2011. 2011;5:3702-10.

4. Park J, Kim K, Kim N, Choi I, Lee S, Tak S, et al. A Comparison of Cervical Flexion, Pain, and Clinical Depression in Frequency of Smartphone Use. Int J Bio-Science Bio-Technology [Internet]. 2015 [cited 2017 Jan 30];7(3):183-90. Available from:

http://dx.doi.org/10.14257/ijbsbt.2015.7.3.19

5. Naser SSA, Almursheidi SH. A Knowledge Based System for Neck Pain Diagnosis. 2016;2(4):128.

6. Evans G. Identifying and Treating the Causes of Neck Pain. Med Clin North Am. 2014;98(3):64561. dilakukan tindak lanjut dalam menangani permasalahan nyeri leher yang dialami pada dewasa muda dengan sosialisasi penggunaan telepon pintar dengan posisi badan dan leher yang benar.

7. Karaeng $M$, Djajakusli $R$, Furqaan Naiem $M$. Hubungan Beban Kerja Dengan Nyeri Leher Pada Tenaga Kerja Bongkar Muat Di Koperasi Tenaga Kerja Bongkar Muat Pelabuhan Makassar. 2012.

8. Kim H-J, DH, Kim J-S. The relationship between smartphone use and subjective musculoskeletal symptoms and university students. J Phys Ther Sci. 2015 Mar;27(3):575-9.

9. Almhdawi KA, Mathiowetz V, Al-Hourani Z, Khader $Y$, Kanaan SF, Alhasan $M$. Musculoskeletal pain symptoms among allied health professions' students: Prevalence rates and associated factors. J Back Musculoskelet Rehabil. 2017 Nov 6;30(6):1291-301.

10. Lee S, Choi Y-H, Kim J. Effects of the cervical flexion angle during smartphone use on muscle fatigue and pain in the cervical erector spinae and upper trapezius in normal adults in their 20s. J Phys Ther Sci. 2017 May;29(5):921-3.

11. Toh SH, Coenen P, Howie EK, Straker LM. The associations of mobile touch screen device use with musculoskeletal symptoms and exposures: A systematic review. PLoS 2017;12(8):e0181220.
One. 